УДК 618.175-06:616.36-002.2]-039.71:618.2

DOI 10.11603/24116-4944.2016.2.6866

\author{
๑Л. Є. Лимар ${ }^{1}$, Н. А. Лимар ${ }^{2}$, Н. Д. Коблош ${ }^{3}$ \\ ${ }^{1}$ ДВНЗ «Тернопільсъкий державний медичний університет \\ імені І. Я. Горбачевсъкого МОЗ України» \\ ${ }^{2}$ КЗ ТОР ТОКПЦ «Мати і дитина» \\ ${ }^{3}$ ДУ «Інститут педіатріӥ, акушерства $і$ гінекологї \\ Національної акаде мії медичних наук України»
}

\title{
РИЗИКИ РЕАЛІЗАЦІЇ РЕПРОДУКТИВНОЇ ФУНКЦІЇ У ЖІНОК ІЗ ПОРУШЕННЯМИ МЕНСТРУАЛЬНОЇ ФУНКЦІї НА ТЛІ ХРОНІЧНИХ ГЕПАТИТІВ І ШЛЯХИ ЇХ УСУНЕННЯ
}

РИЗИКИ РЕАЛІЗАЦІЇ РЕПРОДУКТИВНОЇ ФУНКЦІЇ У ЖІНОК ІЗ ПОРУШЕННЯМИ МЕНСТРУАЛЬНОЇ ФУНКЦІЇ НА ТЛ ХРОНІЧНИХ ГЕПАТИТІВ І ШЛЯХИ ЇХ УСУНЕННЯ. Реалізація репродуктивної функції є серйозною проблемою сьогодення, оскільки впродовж останнього десятиліття спостерігається від'ємний демографрічний показник не лише в Україні, а й у багатьох країнах світу. За оцінкою Державної служби статистики України, станом на 1 квітня 2016 р. чисельність наявного населення України становила 42708 тис. осіб. Дослідження науковців Інституту демограсії та соціальних досліджень свідчать, що кількість померлих компенсується новонародженими лише на 52,6 \%, що значно звужує передумови сприятливого демографічного розвитку країни у майбутньому. Причини падіння народжуваності не можна зводити лише до економічних негараздів. Для сучасної демографрічної ситуації в Україні характерні: різке зменшення народжуваності, збільшення смертності і відсутність природного приросту; постаріння населення, збільшення «навантаження» на працездатну його частину; скорочення тривалості життя як чоловіків, так і жінок; погіршення здоров'я нації. Одним із вагомих фракторів зниження репродуктивної функції є порушення менструальної функції (ПМФ) на тлі хронічних гепатитів (ХГ). Нами обстежено 92 жінки репродуктивного віку, які страждають від ПМФ на тлі ХГ різного генезу. Оцінено стан репродуктивного здоров'я, проаналізовані ризики реалізації репродуктивної функції, визначено шляхи їх усунення.

РИСКИ РЕАЛИЗАЦИИ РЕПРОДУКТИВНОЙ ФУНКЦИИ У ЖЕНЩИН С НАРУШЕНИЯМИ МЕНСТРУАЛЬНОЙ ФУНКЦИИ НА ФОНЕ ХРОНИЧЕСКИХ ГЕПАТИТОВ И ПУТИ ИХ УСТРАНЕНИЯ. РеаЛИзация репродУкТИВной фуНнциИ яВляется серьезНоЙ проблемой современности, поскольку в течение последнего десятилетия наблюдается отрицательный демограсический показатель не только в Украине, но и во многих странах мира. Согласно оценке Государственной службы статистики Украины, по состоянию на 1 апреля 2016 г. численность населения Украины составила 42708 тыс. человек. Исследования ученых Института демографии и социальных исследований свидетельствуют, что количество умерших компенсируется новорожденными только на 52,6 \%, что значительно сужает предпосылки благоприятного демографического развития страны в будущем. Причины падения рождаемости нельзя сводить только к экономическим неурядицам. Для современной демографической ситуации в Украине характерны: резкое уменьшение рождаемости, увеличение смертности и отсутствие естественного прироста; старения населения, увеличение «нагрузки» на трудоспособную его часть; сокращение продолжительности жизни как мужчин, так и женщин; ухудшение здоровья нации. Одним из весомых фракторов снижения репродуктивной функции является нарушение менструальной функции (НМФ) на фоне хронических гепатитов (ХГ). Нами обследовано 92 женщины репродуктивного возраста, страдающих НМФ на фоне ХГ различного генеза. Оценено состояние репродуктивного здоровья, проанализированы риски реализации репродуктивной функкции, определены пути их устранения.

RISKS OF REALIZATIONS OF REPRODUCTIVE FUNCTION IN WOMEN WITH MENSTRUAL DYSFUNCTION AND CHRONIC HEPATITIS AND WAYS OF SOLUTION. The implementation of reproductive function is a serious problem today, because in the last decade there has been a negative demographic indicator not only in Ukraine but also in many countries. According to the State Statistics Service of Ukraine, as of April 1, 2016 population of Ukraine was 42708 thousand people. Research of scientists of the Institute of Demography and Social Studies suggest that the number of dead newborn offset by only $52.6 \%$, which significantly reduces preconditions favorable demographic development countries in the future. The causes of fertility decline can not be attributed only to the economic crisis, to the current demographic situation in Ukraine is characterized by: a sharp decrease in the birth rate, increased mortality and lack of natural growth; aging population, increasing the "burden" for the working of it; reducing the life expectancy of both men and women; deteriorating health of the nation. One of the important factors is the decline of reproductive function of menstrual dysfunction (MD) with chronic hepatitis $(\mathrm{CH})$. We examined 92 women of reproductive age suffering from MD against the background of chronic hepatitis different genesis. We reviewed reproductive health, analyzed risks of reproductive function, the ways of their elimination.

Ключові слова: репродуктивна функція, порушення менструальної функції, хронічний гепатит.

Ключевые слова: репродуктивная функция, нарушение менструальной функции, хронический гепатит.

Key words: reproductive function, menstrual dysfunction, chronic hepatitis.

ВСтУп. Для сучасної демограсрічної ситуації в Україні характерні: різке зменшення народжуваності, збільшення смертності і відсутність природного приросту; постаріння населення, збільшення «навантаження» на працездатну 
його частину; скорочення тривалості життя як чоловіків, так і жінок; погіршення здоров'я нації $[1,2]$. Одним із вагомих факторів зниження репродуктивної фрункції $€$ порушення менструальної фрункції (ПМФ) на тлі хронічних гепатитів (ХГ). Захворювання, спричинені дисгормональними розладами, найбільш поширені серед гінекологічної патології і, за даними багатьох авторів, сягають 60-65 \% [3]. Серйозною проблемою $€$ наявність зростання хронічних гепатитів (ХГ), які значною мірою впливають на перебіг гінекологічних захворювань. Порушення менструальної функції проявляються аномальними матковими кровотечами (АМК), дисменореєю, олігоменореєю. Аналіз репродуктивної функції свідчить про значну кількість безпліддя та перинатальних ризиків у жінок з обтяженим гінекологічним анамнезом [3]. Часте поєднання порушень менструальної функції з ХГ взаємно посилює клінічні прояви захворювань, що спонукає науковців до пошуку нових підходів до реабілітації та адекватного лікування даної патології [3-10]. Незважаючи на значний прогрес у розвитку репродуктології, не завжди спостерігається достатній лікувально-профрілактичний ефект, особливо при супутній екстрагенітальній патології [3-10]. Сучасний розвиток медицини передбачає постійне удосконалення заходів щодо діагностики, лікування та профрілактики захворювань 3 урахуванням вимог доказової медицини [3-10]. Нами обстежено 92 жінки репродуктивного віку, які страждають від ПМФ на тлі ХГ різного генезу. Оцінено стан репродуктивного здоров'я, проаналізовані ризики реалізації репродуктивної фрункції, визначено шляхи їх усунення.

Метою нашого дослідження було вивчити зміни менструальної фрункції у жінок репродуктивного віку при хронічних гепатитах різного генезу та проаналізувати їх вплив на репродуктивну фрункцію, виявити ризики реалізації репродуктивної функції та визначити шляхи їх усунення.

МАТЕРІАЛИ ТА МЕТОДИ. Нами обстежено 152 жінки репродуктивного віку з порушеннями менструальної фрункції (аномальні маткові кровотечі, олігоменорея), в тому числі 92 жінки на тлі хронічних гепатитів. 3 них 17 жінок на тлі ХГ вірусного генезу, 75 жінок мали порушення менструальної фрункції на тлі ХГ невірусного генезу, 60 жінок 3 порушеннями менструальної функції не мали патології печінки і служили контролем порівняння.

Для діагностики ХГ використовували анамнез, об'єктивні клінічні прояви, лабораторні методи. Визначали маркери вірусних гепатитів: антигенні; серологічні; генетичні - вірусна ДНК або РНК. Для визначення активації процесу визначали такі біохімічні показники, як: тимолова проба, аланінамінотранссераза (АлАТ), аспартатамінотрансфераза (АсАТ), лужна фросфатаза (ЛФ), у-глутаматамінотрансоераза (ГГТ), білірубін, протромбін, холестерин, білок, лейкоцитоз. Всім пацієнткам проводили клінічне обстеження, УЗД геніталій, органів черевної порожнини, загальноприйняте лабораторне обстеження. Оцінювали репродуктивну функцію, а саме: паритет, перебіг вагітностей, ускладнення вагітності, пологів, післяпологового періоду.

РЕЗУЛЬТАТИ ДОСЛІДЖЕННЯ ТА ЇХ ОБГОВОРЕННЯ. Нами обстежено 152 жінки з порушеннями менструальної фрункції. 3 них 17 жінок на тлі ХГ вірусного генезу, а саме: 11 пацієнток з гепатитом B, 5 з гепатитом C та 1 з гепатитом D. 75 жінок мали порушення менструальної фрункції на тлі ХГ невірусного генезу, а саме: 47 жінок страждали від ХГ токсичного генезу; у 9 хворих діагностовано хронічний медикаментозний гепатит; у 13 пацієнток виявлено аутоімунний ХГ; 2 хворих мали ХГ алкогольного генезу; у 4 пацієнток був ХГ криптогенного генезу. 60 жінок 3 порушеннями менструальної фрунції не мали патології печінки і служили контролем для порівняння виявлених змін репродуктивної функції.

Діагностика ХГ базувалась на даних анамнезу (вірусний гепатит $\mathrm{B}$ або $\mathrm{C}$, або $\mathrm{D}$; професійні, хімічні шкідливі чинники; медикаментозні інтоксикації; зловживання алкоголем; підпечінковий холестаз; метаболічні порушення). Всім пацієнткам проводилось ультразвукове дослідження. Для діагностики загострення ХГ використовувались результати клінічних проявів захворювання: гепатолієнальний, диспептичний, астеновегетативний, холестатичний, геморагічний, синдром портальної гіпертензії. Для підтвердження активаціх ХГ проводились лабораторні дослідження - визначались маркери вірусних гепатитів: HBsAg, HвcAg; анти-HBs, анти-HBe, анти-HBc, анти-НВс - IgM, анти-HCV, анти-HCV - IgM; вірусна ДНК або РНК. Біохімічні показники: тимолова проба; АлАТ; білірубін; лейкоцитоз; лужна фросфатаза; протромбіновий індекс $<80 \%$.

Середній вік обстежуваних жінок у досліджуваних групах становив: у групі жінок з вірусними ХГ 32,7 року; у групі жінок 3 невірусними гепатитами 33,6 року, у контрольній групі 29,7 року. Тривалість захворювання ХГ продовжувалась від 2 до 13 років. У пацієнток обох груп загострення вказаних захворювань були пропорційними. Середня тривалість гінекологічного захворювання в усіх групах коливалась від 3 до 14 років. Серед ПМФ спостерігались такі клінічні прояви: аномальні маткові кровотечі (АМК) в поєднанні з дисменореєю у 11 (64,7\%) жінок з вірусними ХГ та 51 (68,0 \%) жінки 3 невірусними ХГ; олігоменорея при вірусних ХГ спостерігалась у 6 жінок (35,3\%), при невірусних гепатитах олігоменорея була у 24 жінок (32,0 \% випадків), що підтверджується даними наших попередніх досліджень. В літературі, доступній для опрацювання, ми не знайшли подібних досліджень. Проведений ретроспективний аналіз репродуктивної фрункції обстежуваних жінок. Первинне безпліддя спостерігалось у 29 жінок (31, 5 \%), які страждають від ХГ. 3 них 13 (14,1 \%) не реалізували репродуктивну фрункцію до нашого дослідження. Невиношування виявлене у 55 (59,8 \%) цієї категорії жінок. При цьому ранні викидні відбулися у 47 (51,1 \%). У 22 (23,9 \%) з цих пацієнток діагностовано вторинне безпліддя. Пізні викидні спостерігались у 2 (2,2 \%). Передчасні пологи відбулися у 6 (6,5 \%) жінок з ПМФ в анамнезі на тлі ХГ. Аналіз репродуктивної функції жінок з ПМФ в анамнезі без супутньої патології печінки виявив наступне: безпліддя спостерігалось у 12 (20,0 \%) жінок; невиношування виявлене у 21 (35,0 \%) випадку. Ранні викидні спостерігались у 17 (28,3\%); пізні викидні відбулися у 3 (5,0 \%) жінок; передчасні пологи - в 1 (1,7 \%) жінки. Слід зауважити, що переривання вагітності відбувалося на тлі загострення ХГ. Отримані результати дослідження дають підставу прогнозувати порушення реалізації репродуктивної функції у жінок з ПМФ на тлі ХГ. Шляхи усунення цієї проблеми полягають у своєчасному виявленні ПМФ та супутньої патології, адекватному комплексному лікуванні та проведенні повноцінної прегравідарної підготовки вказаного контингенту жінок. 
ВИСНОВКИ. 1. Проведені дослідження доводять, що у жінок репродуктивного віку з розладами менструальної фрунції у вигляді АМК, олігоменореї на тлі ХГ спостерігаються порушення репродуктивної фрункції.

2. Виявлені прояви ПМФ в анамнезі зумовлюють первинне і вторинне безпліддя та невиношування вагітності.
3. У жінок з ПМФ на тлі ХГ безпліддя спостерігається в 1,5 раза частіше, невиношування вагітності в 2 рази частіше, ніж у жінок з ПМФ без ХГ.

ПЕРСПЕКТИВИ ПОДАЛЬШИХ ДОСЛІДЖЕНЬ. ПЛАнуються подальші дослідження порушень менструальної срункції при ХГ та їх вплив на реалізацію репродуктивної функцції.

\section{СПИСОК ЛІТЕРАТУРИ}

1. Концепція демографрічного розвитку України на 20052015 рр. Проект. - К., 2004. - С. 4.

2. Кульчицький С. В. Демографрічні втрати України / С. В. Кульчицький // Енциклопедія сучасної України : в 30 т. К. : Національна академія наук України, Наукове товариство імені Шевченка, Координаційне бюро енциклопедії сучасної України НАН України, 2001-2016.

3. Дубоссарская 3. М. Теория и практика гинекологической эндокринологии / 3. М. Дубоссарская. - Днепропетровск, 2005. - 409 c.

4. Радченко В. Г. Основы клинической гепатологии / В. Г. Радченко, А. В. Шабров, Е. Н. Зиновьева. - СПб., 2005. - 860 c.

5. Ильченко Л. Ю. Хронические вирусные гепатиты: перспективы и достижения / Л. Ю. Ильченко, Г.Н.Якимчук // Экспериментальная и клиническая гастроэнтерология. 2007. - № 2. - C. 34-38.
6. Про організацію надання акушерсько-гінекологічної та неонатологічної допомоги в Україні : наказ № 620. - К., 2003.

7. Про затвердження клінічних протоколів з акушерської та гінекологічної допомоги : наказ № 676. - К., 2004.

8. Уніфрікований клінічний протокол первинної, вторинної (спеціалізованої) медичної допомоги. Аутоімунний гепатит : наказ Міністерства охорони здоров'я України № 826. - К., 2014.

9. Lenaerts C. Surveillance for cystic fibrosis-associated hepatobiliary disease:early ultrasound changes and predisposingfactors / C. Lenaerts, C. Lapierre, H. Patrquin // J. Pediatr. - 2003. - Vol. 143. - P. 343-50.

10. Wedemeyer H. Fatty. Liver Disease / H. Wedemeyer, M. P. Manns. - Conference Report: $38^{\text {th }}$ Annual Meeting of the Europen Association for the Study of the Liver(EASL); Geneva, Switzerland, July 3-6, 2003. 